UDC 378.147.811

DOI https://doi.org/10.31470/2415-3729-2021-13-79-95

\title{
The Effectiveness of Testing as a Method of Pedagogical Control of Future Specialists With Higher Education
}

\section{Roman Horbatiuk}

Doctor of Pedagogical Sciences, Professor, Head of the Mechanical Engineering and Transport Department,

Ternopil Volodymyr Hnatiuk National Pedagogical University

$\triangle$ Maksyma Kryvonosa Str., 2, Ternopil, Ukraine, 46027

E-mail: gorbaroman@gmail.com

ORCID: http://orcid.org/0000-0002-1497-1866

\section{Stepan Sitkar}

Doctor of Philosophy in Pedagogy (Ph.D), Assistant Professor of the Mechanical Engineering and Transport Department, Ternopil Volodymyr Hnatiuk National Pedagogical University

$\triangle$ Maksyma Kryvonosa Str., 2, Ternopil, Ukraine, 46027

E-mail: sitkars@gmail.com

ORCID: http://orcid.org/0000-0003-4599-454X

\section{Taras Sitkar}

Doctor of Philosophy in Pedagogy (PhD), Associate Professor of Computer Technology Department,

Ternopil Volodymyr Hnatiuk National Pedagogical University

$\triangle$ Maksyma Kryvonosa Str., 2, Ternopil, Ukraine, 46027

E-mail: sitkar@gmail.com

ORCID: http://orcid.org/0000-0002-5120-341X

\section{Svitlana Konovalchuk}

Doctor of Philosophy in Pedagogy (PhD), Assistant professor of Romanic and Germanic Philology Department

Ternopil Volodymyr Hnatiuk National Pedagogical University

$\triangle$ Maksyma Kryvonosa Str., 2, Ternopil, Ukraine, 46027

E-mail: Svitlanakonoval@yahoo.com

ORCID: http://orcid.org/0000-0003-1116-7925

\section{Nazar Burega}

Doctor of Philosophy in Technics (PhD), Assistant professor of Mechanical Engineering and Transport Department,

Ternopil Volodymyr Hnatiuk National Pedagogical University

$\triangle$ Maksyma Kryvonosa Str., 2, Ternopil, Ukraine, 46027 
E-mail: buregan@ukr.net

ORCID: http://orcid.org/0000-0002-7541-633X

Date of receipt of the article: April 17, 2021

Article accepted for publication: June 02, 2021

Ефективність тестування як методу педагогічного контролю майбутніх фахівців з вищою освітою

\section{Роман Михайлович Горбатюк}

доктор педагогічних наук, професор, завідувач кафедри машинознавства і транспорту,

Тернопільський національний педагогічний університет ім. В. Гнатюка вул. вул. Максима Кривоноса, 2, м. Тернопіль, Україна, 46027

\section{Степан Вікторович Сіткар}

кандидат педагогічних наук, викладач кафедри машинознавства і транспорту,

Тернопільський національний педагогічний університет ім. В. Гнатюка вул. вул. Максима Кривоноса, 2, м. Тернопіль, Україна, 46027

\section{Тарас Вікторович Сіткар}

кандидат педагогічних наук, доцент, доцент кафедри комп'ютерних технологій,

Тернопільський національний педагогічний університет ім. В. Гнатюка $\checkmark$ вул. вул. Максима Кривоноса, 2, м. Тернопіль, Україна, 46027

\section{Світлана Андріївна Коновальчук}

кандидат педагогічних наук, асистент кафедри романо-германської філології, Тернопільський національний педагогічний університет ім. В. Гнатюка вул. вул. Максима Кривоноса, 2, м. Тернопіль, Україна, 46027

\section{Назар Васильович Бурега}

кандидат технічних наук, викладач

кафедра машинознавства і транспорту,

Тернопільський національний педагогічний університет ім. В. Гнатюка вул. вул. Максима Кривоноса, 2, м. Тернопіль, Україна, 46027

Дата надходження статті: 17 квітня 2021 р. Стаття прийнята до друку: 02 червня 2021 p.

\section{Abstract}

The article deals with the effectiveness of testing as a method of pedagogical control of the professional knowledge of future specialists 
with higher education. The purpose of the article is to describe the advantages and disadvantages of mass control technologies, the reasons of weak development of pedagogical testing in domestic practice, to give recommendations for a partial solving the problems with the introduction of pedagogical testing. Methods. The authors implement the purpose with the help of such methods as analysis, comparison, generalization, systematization, testing. The results. The authors state that with the paradigm shift in education the main role in controlling the student's knowledge was shifted to testing, which gave us the possibility to reduce a teacher's workload and reduce the time for the process of knowledge control itself, as well as to activate the process of self-control among students. The authors emphasize that due to the modern requirements for professional knowledge of future specialists with higher education, they must have an advanced level of information culture and skills to work with printed and electronic source of information, systematize and interpret the professional information which they have obtained during the reading task. There is a description of two insights as for the advantages and disadvantages of mass control technologies in the article. The reasons of weak development of pedagogical testing in domestic practice have been also described. The recommendations for a partial solving the problems with the introduction of pedagogical testing have been given. Conclusions. The article deals with a method of problem solving of education management efficiency. It's considered as a minimization of time to achieve the advanced level of success in a particular topic. In addition, the mathematical description of the success function and the function of time-consuming have been given in the article. Due to these, a method of minimizing training time for proving the required level of success has been obtained. The article suggests also a description of the applying of a given model for the education structure adaptive management, which saves the substantial time and teacher's workload without losing the quality of learning material. The authors make an attempt to define the reasons for the absence of testing at the Ukrainian educational services market.

Key words: pedagogical testing, pedagogical control, testology, knowledge attestations, skills and abilities.

\section{References}

1. Boliubash, Ya. Ya., Bulakh, I. Ye., Mruha, M. R. \& Filonchuk, I. V. (2007). Pedahohichne otsiniuvannia i testuvannia. 
Pravyla. Standarty. Vidpovidalnist. Naukove vydannia [Pedagogical assessment and testing. Rules. Standards. Responsibility]. Kyiv : Maister-klas [in Ukrainian].

2. Bulakh, I. Ye., \& Mruha, M. R. (2006). Stvoriuiemo yakisnyi test [We create a quality test]. Kyiv : Maister-klas [in Ukrainian].

3. Horbatiuk, R. M. \& Kabak V. V. (2020). Monitorynh yakosti navchalnoi diialnosti maibutnikh inzheneriv-pedahohiv yak pedahohichna problema [Monitoring the Quality of the Initial Performance of the Potential Engineer-Pedagogues as a Pedagogical Problem]. Profesiina osvita: metodolohiia, teoriia ta tekhnolohii - Professional Education: Methodology, Theory and Technologies. 12, 45-55 [in Ukrainian].

4. Horbatiuk, R. M. \& Romanyshyna L. M.

(2016). Eksperymentalna model dystantsiinoho navchannia maibutnikh fakhivtsiv u vyshchomu navchalnomu zakladi [Experimental model of distance education future experts in higher educational institutions]. Naukovi zapysky Ternopilskoho natsionalnoho pedahohichnoho universytetu imeni V. Hnatiuka. Seriia: Pedahohika - The scientific issues of ternopil volodymyr hnatiuk national pedagogical university. series: pedagogy, 2, 69-75 [in Ukrainian].

5. Kartashova, I. I. \& Prokhorenkov V. M. (2013). Testuvannia $v$ systemi monitorynhu yakosti znan studentiv [Testing in the system of monitoring the quality of students' knowledge]. Kherson : Vyd-vo KhDU [in Ukrainian].

6. Liashenko, O.I. \& Zhuka, Yu.O (Eds.) (2014). Testovi tekhnolohii otsiniuvannia kliuchovykh i predmetnykh kompetentnostei uchniv osnovnoi $i$ starshoi shkoly [Test technologies for assessing the key and subject competencies of primary and secondary school pupils]. Kyiv : Pedahohichna dumka [in Ukrainian].

7. Yaroshchuk, L. H. (2010). Osnovy pedahohichnykh vymiriuvan ta monitorynhu yakosti osvity [Fundamentals of pedagogical measurements and monitoring of education quality]. Kyiv : Slovo [in Ukrainian].

8. Bondarenko, M. et al (2009). Tehnologiya otsenivaniya testov $\mathrm{v}$ zavisimosti of tipa i urovnya slozhnosti testovyih zadaniy na osnove integrirovannoy modeli [Technology of test evaluation depending on the type and level of complexity of test tasks based on an integrated 
model]. Proceedings of the Fourth International Conference «Modern (e-) Learning» MeL 2009. Varna, Bulgaria, June-July 2009, 55-62 [in Russian].

9. Melnyk, A. M., Melnyk, A. M. \& Pasichnyk, R. M. (2009). Model otsinky skladnosti testovykh zavdan [Model for estimating the complexity of test tasks]. Naukovyi visnyk Chernivetskoho universytetu : Kompiuterni systemy ta komponenty - Scientific Bulletin of Chernivtsi University: Computer Systems and Components, 2009, 479, 108-11 [in Ukrainian]3 .

10. Pasichnyk, R., Melnyk, A., Pasichnyk, R. \& Turchenko, I. (2011). Method of Adaptive Control Structure Learning Based on Model of Tests Complexity. Intelligent Data Acquisition and Advanced Computing Systems: Technology and Applications Proceedings of the 6th IEEE International Conference IDAACS 2011, Volume 2 (Prague, Czech Republic, 15-17 September 2011) / IEEE Ukraine I\&MCI Joint Societies chapter, Research Institute for Intelligent Computer Systems [and other], 692-695.

11. Melnyk, A. M. (2012). Informatsiina tekhnolohiia avtomatychnoi heneratsii testovykh zavdan $\mathrm{z}$ kerovanoiu skladnistyu [Information technology of tests automatic generation with controlled complexity]. Candidate's thesis. Ternopil [in Ukrainian].

12. Antonyk, M. S. (2005). Informatsiina tekhnolohiia pobudovy avtomatyzovanoi systemy upravlinnia navchalnym protsesom [Information technology of construction of the automatic control system for the education process]. Extended abstract of candidate's thesis. Lviv [in Ukrainian].

13. Nosov, P. S. (2007). Intelektualne formuvannia indyvidualnoi traiektorii navchannia studenta [The intellectual formation of the individual trajectory of students' teaching]. Extended abstract of candidate's thesis. Odesa [in Ukrainian].

14. Melnyk, A. M. \& Pasichnyk, R. M. (2011). Metod adaptyvnoho upravlinnia strukturoiu protsesu navchannia [Method of adaptive management of the structure of the learning process]. Visnyk Khmelnytskoho natsionalnoho universytetu - Scientific Journal Herald of Khmelnytskyi National University, 1, 132-137 [in Ukrainian].

15. Melnyk, A. M.\& Pasichnyk, R. M. (2009). Modeliuvannia rezultatyvnosti navchannia $\mathrm{V}$ intelektualnykh adaptyvnykh 
navchalnykh systemakh [Modeling the effectiveness of learning in intelligent adaptive learning systems]. Mizhnarodnyi naukovotekhnichnyi zhurnal "Informatsiini tekhnolohii ta kompiuterna inzheneriia» - The international scientific and technical journal "Information Technology and Computer Engineering», 3, 107116 [in Ukrainian].

16. Serhiienko, V. P., Malezhyk, M. P. \& Sitkar, T. V. (2012). Kompiuterni tekhnolohii $v$ testuvanni [Computer technology in testing]. Lutsk : SPD Hadiak Zhanna Volodymyrivna, drukarnia «Volynpolihraf» ${ }^{\mathrm{TM}}$ [in Ukrainian].

\section{Вступ}

Актуальність дослідження зумовлена сучасними вимогами до професійних знань майбутніх фахівців 3 вищою освітою, які мають володіти високим рівнем інформаційної культури, здатні орієнтуватися в друкованих та електронних джерелах інформації, систематизувати й інтерпретувати одержані під час читання професійні відомості.

На сьогоднішній день в нашій державі склалася ситуація коли збільшується кількість громадян, які хочуть отримати вищу педагогічну освіту за умови мінливого збільшення вимог до майбутніх фахівців. Тому природним й умотивованим $є$ те, що здобувачам вищої освіти у процесі навчання доводиться засвоювати значний обсяг інформаційних ресурсів, формувати вміння та навички, які будуть необхідні для майбутньої професії. Допомогу у вирішенні цього завдання покладають на інформаційнокомунікаційні технології (IКТ). Створення та широке застосування комп'ютерної техніки, засобів передачі й обміну інформацією спонукає до створення різних програмних засобів навчального призначення (ПЗНП).

Метою статті є описати переваги та недоліки технологій масового контролю, причини слабкого розвитку педагогічного тестування у вітчизняній практиці, дати рекомендації щодо часткового вирішення проблем із упровадженням педагогічного тестування.

\section{Матеріал і методи дослідження}

У процесі дослідження застосовано наступні методи: аналіз, порівняння, узагальнення та систематизація, тестування. 


\section{Результати та їх обговорення}

Моніторинг сформованості фахових знань наразі є одним iз головних завдань педагогіки. Для оперативної перевірки сформованості фахових знань у педагогіці застосовують тестові завдання. Через швидкі темпи розвитку техніки та технологій, дистанційного навчання великого поширення набуло комп'ютерне тестування. Так, під час дистанційного навчання, коли немає прямого контакту між науково-педагогічними працівниками і здобувачами вищої освіти, на перше місце виходить комп'ютерне тестування як засіб перевірки та контролю знань, умінь та навичок. Саме тому, виникає проблема у створенні тестів і тестових технологій, які могли б швидко, точно, надійно, об'єктивно та адекватно оцінити рівень знань тих, хто навчається. При сучасному розвитку рівня техніки та широкому застосуванні комп'ютерного тестування, окрім самих тестів потрібно розвивати й автоматизовані системи, які дадуть змогу реалізовувати всі властивості тестів і тестових технологій.

Сучасні умови розвитку суспільства дали поштовх модернізації освітньої системи, іiі форм і методів. З'явилася необхідність удосконалення та розробки нових підходів щодо оцінювання якості знань. Одним із важливих $є$ тестовий контроль, дослідженням якого займається такий науковий напрям, як тестологія. Перевагами використання тесту, як елементу комплексної оцінки якості знань, є однакові умови для всіх здобувачів вищої освіти, єдність інструкцій та чітке їх розуміння. Такі принципи покладено в основу стандартизації процедури проведення тестування.

До продуктів системи освіти відносять знання, уміння і навички, які були передані здобувачам вищої освіти та засвоєні ними. Першочергове значення для подальшого розвитку суспільства має якість цієї освітньої продукції.

В освіті для виміру якості застосовують поурочний, рубіжний, підсумковий та інший види контролю. Кожен вид контролю характеризується відповідною технологією.

На думку багатьох науковців [1-4], найбільш об’єктивна технологія масового контролю повинна бути не залежною від будь-яких суб'єктивних впливів, автоматична та одноманітна. 
Проте, у цієї точки зору є і супротивники [5; 6], які вважають, що контроль повинен проводитися «очі в очі».

Вважаємо, що слабкими моментами першої точки зору є: неможливість автоматизованими засобами перевірити та адекватно оцінити уміння:

- формулювати власні думки;

- знаходити оригінальні рішення;

- навчати і навчатися.

До недоліків другої точки зору можемо віднести:

- високу вартість;

- відсутність гарантії об'єктивності;

- не достатня кількість кадрів потрібної кваліфікації, які здатні неупереджено та однаково оцінити значну кількість претендентів.

Для вирішення і подолання недоліків обох точок зору, вважаємо за доцільне, приймати «філософську» позицію, тобто знаходити золоту середину. Наприклад:

- здійснювати контроль знань рутинних відомостей, уміння виконувати стандартні дії автоматичними засобами - тобто все те, що відносять до «заліку»;

- здійснювати контроль умінь мислити та подавати власні думки, а також інші властивості, які неможливо контролювати за допомогою засобів автоматизації силами педагогічних фахівців.

Атестація знань, вмінь та навичок - це різносторонній контроль, що здійснюється тією технологією, яка $є$ найбільш об'єктивною з усіх можливих, 3 видачею документу, який буде визнаватися в суспільстві. Вона (атестація) є важливим елементом освітнього процесу. Об'єктивність атестації - це один з елементів гарантії того, що суспільство розвивається.

У сучасному світі розроблено та впроваджено безліч підходів до атестації знань, умінь і навичок, заснованих на застосуванні інформаційно-комунікаційних технологій. Значну частину 3 них визнано досить об' єктивними.

Однак серед відомих комп'ютерних навчальних і тестуючих комплексів досить складно знайти такі, які б абсолютно витримували зауваження $з$ погляду:

- об'єктивності;

- зручності; 
- привабливості;

- повноту набору необхідних функцій контролю та подання результатів;

- об'ємності змісту.

Виключенням є професійні військові тренажери (які досить часто були створені за кордоном нашими співвітчизниками).

Це зв'язано з декількома причинами:

- в нашій державі педагогічне тестування довгий час було під забороною нормативних документів i, як результат, ми повинні наздоганяти інші країни в цій області;

- початок розвиток технологій комп'ютерного тестування в нашій країні співпав 3 періодом економічної кризи;

- розвиток якісних вітчизняних комп'ютерних комплексів пригальмовує матеріалістичне ставлення до результату їх застосування, що опирається на звичайну економічну складову. Для того, щоб будь-якому продукту надати перераховані вище якості - потрібні значні фінансові витрати;

- культура виробництва у нашій державі дуже низька у порівнянні 3 іншими країнами, де підприємцеві не все рівно, які саме кадри він приймає на роботу, і де підприємці досить давно використовують автоматизовані методи для контролю знань, умінь та навичок. Працедавці в нашій країні досить рідко переймаються важливістю таких заходів.

До недоліків традиційних систем оцінювання й атестації знань, умінь і навичок віднесемо:

- суб' єктивне ставлення;

- не систематичність;

- нечіткість вимог та режимів контролю;

- важкість забезпечення секретності під час зберігання екзаменаційних матеріалів та захисту їх від фальсифікації;

- присутність випадкових, нерегулярних помилок вимірів;

- відсутність однозначних математичних критеріїв оцінки.

Більшість з описаних вище недоліків можна вирішити за допомогою застосування комп'ютерних технологій. Однак, наразі це - лише побажання, яке підтверджене теоретично. Ідеальної системи автоматизованого контролю знань, умінь та навичок наразі не існує. Пов’ язано це з багатьма причинами: 
- різнорідністю, частою зміною та відносною незрілістю (молодістю) як інформаційних технологій, так і відповідного технічного забезпечення;

- відсутністю належної державної підтримки розробки і впровадження;

- відсутністю кваліфікованих фахівців;

- відсутність відповідної теоретичної бази.

Можливість вирішення зазначених проблем пов'язані з новими управлінськими рішеннями та заходами, а саме:

- державною підтримкою розвитку тестології як галузі знань і науки;

- створенням індустрії систем тестового контролю.

Із зміною парадигми в освіті основна роль в контролі знань була перекладена на тестування. Це дозволило зменшити навантаження на викладача та зменшити час на сам процес контролю знань, а також активізувати процес самоконтролю у студентів. Як було доведено багатьма науковцями якісь самоконтролю буде зростати тоді коли тестові завдання будуть впорядковані за наростанням складності. Питання оцінки складності досить добре розкриті у науковій літературі та досліджувалися у роботах $[8 ; 9 ; 10]$. У роботі [11] запропонований ефективний підхід до оцінки складності тестових завдань на основі мало-параметричної регресійної моделі, параметри якої ідентифікуються по невеликій вибірці тестів для конкретних студентських аудиторій та типів тестових завдань. Такий підхід дає можливість для генерації рівноцінних наборів тестових завдань, а також забезпечує адаптацію студентів до зростання рівня їх складності.

Проте наукові дослідження свідчать, що диференціювання складності завдань дає можливість керувати тривалістю підготовки по тестах для отримання реально досяжного рівня успішності за сукупністю предметів при обмеженому ресурсі часу відведеного на підготовку.

У роботі [12] був запропонований абстрактний класифікаційний підхід. Однак цей підхід не враховує індивідуальні особливості студентів. А в праці [13] застосовується формування індивідуальної траєкторії навчання. Проте цей підхід базується на врахуванні значної кількості суб'єктивних оцінок важко спостережуваних факторів. 
У сучасній системі освіти процес контрольного тестування рівня знань має дискретний характер. Тобто успішність за курс $\epsilon$ зваженою оцінкою успішності з кожного залікового модуля. Ці модулі певною мірою пов'язані із змістовими модулями, які в свою чергу ділять навчальний семестр на періоди по 5-9 тижнів. Інколи тестовий контроль рівня знань може проводитись 3 кожної окремої теми. Тоді час на їх вивчення ще більше скорочується. Отже можна зробити висновок, що на протязі такого незначного періоду раціонально можна отримати лише 3-5 проміжних результатів тестування. При такій незначній вибірці модель залежності успішності студента від часових затрат може містити лише мінімальну кількість параметрів.

Нехай матеріал в навчальній системі згруповано за темами tm. При ознайомлені з матеріалом кожної теми студент $\mathrm{s}$ виконує навчальні тести рівнів складності $\mathrm{k}$, що стимулюють процес засвоєння навчального матеріалу. Після освоєння матеріалу розділу студент складає контрольні тести 3 теми [14; 15$]$.

Відповідно до результатів навчального тестування можна спрогнозувати результати контрольного тестування. Після цього прогнозування студентові видається цей прогноз і якщо він його не задовольняє, тоді той, що тестується, повинен докласти більше зусиль для досягнення вищої успішності, тобто його спрямовують на виявлення слабо засвоєного матеріалу та його переосмислення. Таким чином з ростом успішності зменшується питома частка слабозасвоєного матеріалу, проте збільшується час на надійну ідентифікацію слабких місць. Дослідження показують, що для моделювання залежності успішності від часових витрат необхідно використати монотонно зростаючу степеневу залежність.

Оскільки процес навчання носить не статичний, а динамічний характер, то логічно було б його організувати 3 використанням навчальних матеріалів із наростаючою складністю. Ідентифікація може бути здійснена на основі адаптивно-структурного методу [9]. Ще одним важливим моментом у побудові системи тестування є встановлення моменту часу коли потрібно підвищити складність завдань так щоб студент докладав мінімум часу для досягнення бажаної успішності. Однак під час побудови залежності для оцінки часових затрат мож- 
на отримати для одного значення аргументу декілька значень функції. Тому для усунення цього недоліку використовують функцію прогнозованої успішності. Відповідно до цього стає зрозуміло, що функцію часових затрат потрібно брати оберненою до функції успішності.

Задачу управління ефективністю навчання розглядають як мінімізацію часу на досягнення бажаного рівня успішності 3 окремої теми. Спочатку студентові надають можливість пройти тестування 3 усіх рівнів складності, для визначення успішності та оцінки їі динаміки. Після цього переходять до двопараметричної ступеневої апроксимації:

$$
U_{k}^{s, t m, n t}(T)=\left\{\begin{array}{c}
\frac{U_{k}^{s, t m, 1}}{t_{k}^{s, t m, n t}} T, \text { коли } n t=1 \\
\min \left\{A_{k}^{s, t m . n t} T_{k}^{\gamma_{k}^{s, t m, n t}}, 1\right\}, \text { коли } n t>1
\end{array},\right.
$$

де $U_{k}^{s, t m, n t}$ - функція залежності успішності від часових витрат; $\mathrm{t}$ - поточний час ознайомлення із навчальними матеріалами в системі; Т - часові витрати; $A_{k}^{s, t m . n t}, \gamma_{k}^{s, t m, n t ~-~ п а р а м е т р и ~}$ регресійної функції; $n t$ - номер навчального тестового контролю.

Функція часових витрат будується, як обернена до функції успішності

$$
T_{k}^{s, t m, n t}(U)=\left\{\begin{array}{cl}
\frac{t_{k}^{s, t m, n t}}{U_{k}^{s, t m, 1}} U, \text { коли } n t=1 & 0 \leq U \leq \mathbf{1} \\
\left(\frac{\mathbf{U}}{A_{k}^{s, t m \cdot n t}}\right)^{1 / \gamma_{k}^{s, t m, n t}}, \text {, коли } n t>1
\end{array}\right.
$$

де $T_{k}^{s, t m, n t} \quad$ - функція часових витрат, $\mathrm{U}-$ бажаний рівень успішності.

Виходячи з побудови функції успішності та функції часових витрат, був отриманий метод мінімізації часу навчання для забезпечення необхідного рівня успішності, що грунтується на формулах (1.1) та (1.2) [14; 15; 16]. Оптимізаційна задача управління ефективністю навчання, окрім критерію, включає обмеження на 
очікуваний рівень успішності з урахуванням часток тестових завдань відповідної складності в контрольному тесті. Вона також включає природне обмеження на рекомендовані успішності за рівнями складності тестів для конкретного студента та теми навчального матеріалу.

Отже, застосування описаної моделі для адаптивного управління структурою навчання дає суттєву економію часу та навантаження на викладача без втрати якості засвоєння навчального матеріалу.

\section{Висновки}

Сучасні наковці прийшли до суперечки 3 визнанням тестології як повноправної науки. 3 одного боку, загальне визнання тестового контролю дієздатним напрямом дослідження широкого кола педагогічних і психологічних проблем; з іншого - стриманість, неповнота інформації, нерозуміння суті та можливостей.

Можливо, потрібно більше конкретизувати поняття освіти, виразніше продемонструвати його як товар? Отже, де $є$ товар, там $є$ і сертифікація, а відповідно там є і тестування.

В нашій країні вважається правильним проводити тестування продуктів харчування, техніки тощо. Природньо, коли кожен товар має сертифікат то виробник товару використовує захист якості свого товару зі сторони держави. Такі гарантії тестування, які надаються різними незалежними центрами, дають можливість виробникам, покупцям та продавцям цивілізовано захищати свої права. Ці ж гарантії дають можливість об'єктивно провести оцінювання продукції, проводити стратегічне планування свого виробництва.

Тоді виникає логічне запитання: чому ж такого тестування нема на українському ринку освітніх послуг? Існує ряд тому причин:

- немає чіткого математичного визначення освіти;

- працівники в системі освіти не мають достатньої підготовки;

- вкорінення математики в педагогіку - досить далека перспектива; 
- в нашому суспільстві існують відповідні сили, які створюють перешкоди для застосування комп'ютерного тестування (3 комп'ютером складніше домовитись про підміну, ніж з екзаменатором);

- у Законі «Про освіту» відсутнє поняття та роз’яснення про захист якості.

Система освіти має в своєму арсеналі лише поняття ліцензування, акредитація, сертифікація, атестація - тобто тими, які відносяться до формального опису якості.

Література

1. Болюбаш Я. Я., Булах I. Є., Мруга М. Р., Філончук І. В. Педагогічне оцінювання i тестування. Правила. Стандарти. Відповідальність. Наукове видання. Київ : Майстер-клас, 2007. $272 \mathrm{c}$.

2. Булах I. Є., Мруга М. Р. Створюємо якісний тест: навч. посібник. Київ : Майстер-клас. 2006. 160 с.

3. Горбатюк Р. М., Кабак В. В. Моніторинг якості навчальної діяльності майбутніх інженерів-педагогів як педагогічна проблема. Професійна освіта: методологія, теорія та технологї : зб. наук. прац̧ь. Переяслав : Домбровська Я. М., 2020. Вип. 12. 234 с. C. 45-55.

4. Горбатюк Р. М., Романишина Л. М. Експериментальна модель дистанційного навчання майбутніх фахівців у вищому навчальному закладі. Наукові записки Тернопільського начіонального педагогічного університету імені В. Гнатюка. Серія: Педагогіка. 2016. № 2. С. 69-75.

5. Карташова I. I., Прохоренков В. М. Тестування в системі моніторингу якості знань студентів: навчально-методичний посібник. Херсон: Вид-во ХДУ, 2013. 116 с.

6. Тестові технології оцінювання ключових і предметних компетентностей учнів основної і старшої школи: монографія / За ред. Ляшенко О.І., Жука Ю.О. Київ : Педагогічна думка, 2014. 200 с.

7. Ярощук Л. Г. Основи педагогічних вимірювань та моніторингу якості освіти. Київ : Слово, 2010. 296 с.

8. Технология оценивания тестов в зависимости от типа и уровня сложности тестовых заданий на основе интегрированной модели / Бондаренко М. та ін. Proceedings of the Fourth 
International Conference «Modern (e-) Learning» MeL 2009. Varna, Bulgaria, June-July 2009. P. 55-62.

9. Мельник А. М., Пасічник Р. М. Модель оцінки складності тестових завдань. Науковий вісник Чернівеиького університету: Комп 'ютерні системи та компоненти. 2009. № 479. С. 108-113.

10. Pasichnyk R., Melnyk A., Pasichnyk N., Turchenko I. Method of Adaptive Control Structure Learning Based on Model of Test's Complexity. Intelligent Data Acquisition and Advanced Computing Systems: Technology and Applications Proceedings of the 6th IEEE International Conference IDAACS'2011, Volume 2 (Prague, Czech Republic, 15-17 September 2011) / IEEE Ukraine I\&MCI Joint Societies chapter, Research Institute for Intelligent Computer Systems [and other]., 2011. P. 692-695.

11. Мельник А. М. Інформаційна технологія автоматичної генерації тестових завдань 3 керованою складністю : дис. ... канд. тех. наук: 05.13.06 / Тернопіль, 2012. 225 с.

12. Антоник М. С. Інформаційна технологія побудови автоматизованої системи управління навчальним процесом: автореф. дис. на здобуття наук. ступення канд. техн. наук: 05.13.06 / Львів, 2005. 20 с.

13. Носов П. С. Інтелектуальне формування індивідуальної траєкторії навчання студента : автореф. дис. ... канд. техн. наук: 05.13.23 / Одеський національний політехнічний ун-т . Одеса, 2007. $17 \mathrm{c}$.

14. Мельник А. М., Пасічник Р. М. Метод адаптивного управління структурою процесу навчання. Вісник Хмельницького наиіонального університету. 2011. № 1. С. 132-137.

15. Мельник А. М., Пасічник Р. М. Моделювання результативності навчання в інтелектуальних адаптивних навчальних системах. Міжнародний науково-технічний журнал «Інформаційні технології та комп 'ютерна інженерія». 2009. № 3. C. $107-116$.

16. Сергієнко В. П., $\quad$ Малежик М. П., $\quad$ Сіткар Т. В. Комп'ютерні технологї̈ в тестуванні: навч. посіб. Луцьк : СПД Гадяк Жанна Володимирівна, друкарня «Волиньполіграф»тм, 2012. $290 \mathrm{c}$. 
Горбатюк Р. М., Сіткар С. В., Сіткар Т. В., Коновальчук С. А., Бурега Н. В.

Ефективність тестування як методу педагогічного контролю майбутніх фахівців 3 вищою освітою

\section{Анотація}

У статті проведено аналіз ефективності тестування як методу педагогічного контролю професійних знань майбутніх фахівців 3 вищою освітою, які мають володіти високим рівнем інформаційної культури, здатні орієнтуватися в друкованих і електронних джерелах інформації, систематизувати й інтерпретувати одержані під час читання професійні відомості.

Подано опис двох точок зору, щодо переваг та недоліків технологій масового контролю. Описано причини слабкого розвитку педагогічного тестування у вітчизняній практиці. Окрім того подано рекомендації, щодо часткового подолання проблем з упровадженням педагогічного тестування.

В роботі описано спосіб розв'язку задачі управління ефективністю навчання розглядають як мінімізацію часу на досягнення бажаного рівня успішності з окремої теми. Крім того подано математичний опис функції успішності та функції часових витрат. Та отримано за їх допомогою метод мінімізації часу навчання для забезпечення необхідного рівня успішності.

Також подано опис застосування поданої моделі для адаптивного управління структурою навчання, який дає суттєву економію часу та навантаження на викладача без втрати якості засвоєння навчального матеріалу.

Ключові слова: педагогічне тестування, педагогічний контроль, тестологія, атестації знань, умінь і навичок.

\section{Горбатюк Р. М., Ситкар С. В., Ситкар Т. В., Коновальчук С. А., Бу- рега Н. В.}

Эффективность тестирования как метода педагогического контроля будущих специалистов с высшим образованием

\section{Аннотация}

В статье проведен анализ эффективности тестирования как метода педагогического контроля профессиональных знаний бу- 
дущих специалистов с высшим образованием, должны обладать высоким уровнем информационной культуры, способные ориентироваться в печатных и электронных источниках информации, систематизировать и интерпретировать полученные при чтении профессиональные сведения.

Дано описание двух точек зрения, относительно преимуществ и недостатков технологий массового контроля. Описаны причины слабого развития педагогического тестирования в отечественной практике. Кроме того даны рекомендации относительно частичного преодоления проблем с внедрением педагогического тестирования.

В работе описывается решении задачи управления эффективностью обучения рассматривают как минимизацию времени на достижение желаемого уровня успеваемости по отдельной теме. Кроме того подано математическое описание функции успешности и функции временных затрат. И получено с их помощью метод минимизации времени обучения для обеспечения необходимого уровня успеваемости.

Также дано описание применения представленной модели для адаптивного управления структурой обучения, который дает существенную экономию времени и нагрузки на преподавателя без потери качества усвоения учебного материала.

Ключевые слова: педагогическое тестирование, педагогический контроль, тестологии, аттестации знаний, умений и навыков. 